\title{
Zich's Guilt - Reactions to the Concert Performance of Extracts
}

\section{Zichova Vina - ohlasy na koncertní provedení ukázek}

The Structural Approach to Art conference, which was organised by Masaryk University in Brno between June $9^{\text {th }}$ and $10^{\text {th }}$, 2018, included a concert performance of extracts from Otakar Zich's opera Guilt. It was more than decision of logistics - one of the key topics of the conference was the work and personality of Otakar Zich. We therefore wanted both experts and those simply interested to have the opportunity to encounter Zich's artistic work in performance. Considering our interest in Zich's theories of dramatic art, we finally chose his opera Guilt, which was based on Hilbert's play of the same name. We could consider this work thanks to the recent edition by Brian Locke who prepared the score which had existed only in manuscript, or in copies deposited in the archives of the National Theatre. However, it became clear that to produce any extracts with an orchestra was very difficult for operational reasons - Brian Locke had already been working on a version for two pianos, which he kindly provided. Thus, a concert production of the extracts from Zich's Guilt could take place on June $9^{\text {th }}$, 2018. This was 96 years after the premiere and 89 years after the last performance.

Since it was a unique, one should say 'study', staging, whilst at the same time a new presentation of an unknown work
Součástí konference Structural Approach to Art, kterou jsme pořádali 9. a 10. června, bylo mimo jiné i koncertní provedení ukázek z opery Otakara Zicha Vina. Rozhodnutí to bylo více než logické - jedním z podstatných témat konference bylo dílo a osobnost Otakara Zicha, chtěli jsme proto, aby zájemci i odborná veřejnost měli možnost setkat se př́ímo s jeho dílem. Vzhledem k našemu zájmu o Zichovy teorie o dramatickém umění padla nakonec volba na jeho operu Vina, operní verzi Hilbertovy stejnojmenné hry. O provedení tohoto kusu jsme mohli uvažovat díky nedávné edici Briana Locka, který zpracoval partituru léta existující pouze v rukopise či opisech uložených v archivu Národního divadla. Brzy se ovšem ukázalo, že provedení jakýchkoliv ukázek s orchestrem je z provozních důvodů velmi obtížné - Brian Locke měl již rozpracovanou verzi pro dva klavíry, kterou laskavě poskytl. 9. června 2018 tak mohlo proběhnout - devadesát šest let od premiéry a osmdesát devět let od posledního představení - koncertní provedení ukázek ze Zichovy Viny.

Vzhledem k tomu, že šlo o ojedinělé, snad můžeme říct „studijní“ nastudování, a zároveň nové uvedení neznámého díla po téměř více než devadesáti letech, dovolili jsme si požádat rozličné odborníky, aby 
after more than ninety years, we asked sev- se k provedení díla, které sice mohli znát eral experts for their opinion about the $\mathrm{z}$ literatury, ovšem nikoliv $\mathrm{z}$ autopsie, vyproduction of a work they might know jádřili. Krom tří tiskem vydaných recenzí from literature but not from their own ex- (LEŠKA 2018; HOFFMANOVÁ 2018; PAVperience. Apart from three published re- LICA 2018) tak spektrum názorů doplňuje views (LEŠKA 2018; HOFFMANOVÁ 2018; i následující anketa.

PAVLICA 2018), the range of opinions is completed by the following enquiry.

\section{David Drozd}

\section{David Drozd}

Music preparation: Filip Urban

Arrangement for two pianos: Brian Locke

Performance director: Vojtěch Orenič

Cast:

Paní Mařáková: Jitka Zerhauová

Mína Mařáková: Marta Reichelová

Jiří Mařák: Tadeáš Hoza

Stanislav Hošek: Václav Vallon

Karel Uhlír: Aleš Janiga

1st piano: Jiří Hrubý

2nd piano: Jitka Houfová

Introduction (Commentary): Tomáš Žilinský
Hudebni nastudováni: Filip Urban

Úprava pro dva klaviry: Brian Locke

Režie večera: Vojtěch Orenič

\section{Osoby a obsazeni:}

Paní Mařáková: Jitka Zerhauová

Mína Mařáková: Marta Reichelová

Jiří Mařák: Tadeáš Hoza

Stanislav Hošek: Václav Vallon

Karel Uhlír: Aleš Janiga

1. klavír: Jiřri Hrubý

2. klavír: Jitka Houfová

průvodní slovo: Tomáš Žilinský

\section{Associate Professor Helena Spurná}

(Department of Theatre, Film and Media Studies, Palacky University, Olomouc)

Firstly, I would like to highlight Brian Locke's musicological work. He has tirelessly promoted Czech music in the English-speaking world with other music experts, such as Michael Beckerman, John Tyrrell, the conductor Charles Mackerras and the director David Pountney. His role as an 'agent' of Czech modern music abroad is ever so more remarkable because he focuses on composers of a one-time 'mainstream' whose work nowadays barely survives. These compos-

\section{doc. Helena Spurná}

(Katedra divadelních, filmových a mediálních studií UPOL, Olomouc)

$\mathrm{V}$ prvé řadě bych chtěla vyzdvihnout muzikologický počin Briana Locka, který spolu s hudebními odborníky Michaelem Beckermanem a Johnem Tyrrellem, dirigentem Charlesem Mackerrasem či režisérem Davidem Pountneyem po léta neúnavně propaguje českou hudbu v anglofonním světě. Jeho role „agenta“ české moderní hudby v zahraničí je pozoruhodná o to více, že se zaměřuje na skladatele někdejšího „mainstreamu“. Jejich tvorba dnes živoří ve stínu světově proslulých jmen, 
ers are currently overshadowed by worldfamous names such as Dvořák, Janáček and Martinů. However, in their time, they ranked amongst the most-performed composers at concerts and on opera stages. This group contained Foerster, Nová, Jeremiáš, Ostrčil and - last but not least Zich. It must be admitted that Locke does Czech musicology a great favour, especially with his passion in discovering and studying music sources hidden in archives all over the Czech Republic. He is making up for what we have neglected. Now he has plunged into researching the heritage of Jindřich Feld, who has recently passed away and who has been more and more in demand and praised abroad, doing this with the same vigour with which he has promoted Zich's Guilt.

I gained the impression from the performance of Guilt that Brian Locke's editorial efforts had not found a counterbalance in the 'study' transcription of the over-dimensioned orchestral scoring of two piano scores with a vocal part. In my opinion, the several characteristic parts of the opera that we heard did not provide clear proof that Zich's opera might achieve a complete stage production almost 100 years since the premiere and that it belongs to the repertoire of contemporary theatres. This is nothing against the artist - some parts are at least interesting from the point of view of the opera of the period and it shows the high art ambitions of the creator, who was actually a self-taught composer. Only a precise interpretation could shed light on the disputes about how the composer parted from tonal harmonic feeling. The appearance of bitonal and polytonal parts does not constitute the basis of an atonal style as it might appear to jako jsou Dvořák, Janáček či Martinů, ve své době ovšem patřili k nejhranějším autorům na domácích koncertních pódiích a operních scénách (Foerster, Novák, Jeremiáš, Ostrčil či v neposlední řadě také Zich). Je nutno si přiznat, že Brian prokazuje velkou službu české muzikologii, resp. svou vášní pro objevování a studium hudebních pramenů, zasutých v archivech po celé ČR, dohání to, co jsme u nás doma zanedbali. S touž energičností, s níž propaguje Zichovu Vinu, se nyní vrhá do výzkumu pozůstalosti nedávno zesnulého, v zahraničí stále žádaného a oceňovaného skladatele Jindřicha Felda.

Z uvedení Viny jsem nabyla dojmu, že editorské úsilí Briana Locka nenašlo odpovídající protiváhu ve „studijní" transkripci orchestrálně naddimenzované partitury do dvou klavírních partů s vokální složkou. Několik charakteristických částí opery, které jsme vyslechli, dle mého názoru nepodalo jasný důkaz toho, že Zichova opera si po téměř sto letech od premiéry vydobude opětné kompletní jevištní provedení a že patří do repertoáru současných divadel. To není nic proti autorovi, některá místa jsou z hlediska dobové opery přinejmenším zajímavá a svědčí o vysokých uměleckých ambicích a ctižádosti skladatele, který byl v kompozici v podstatě samoukem. Pouze precizní interpretace by vnesla jasno do disputací o tom, jak dalece se skladatel odchýlil od tonálně harmonického cítění. Výskyt bitonálních a polytonálních úseků ještě nezakládá podstatu atonálního stylu, jak se to některým posluchačům po vyslechnutí díla může jevit. Z hlediska kompozičního Zich nevybočil z posmetanovského vývoje české opery se všemi průvodními znaky pozdně romantické komplikovanosti. 
the audience after hearing the piece. From the point of view of the composition, Zich did not deviate from the post-Smetanian development of Czech opera with all its related features of late-romantic complexity. Upon hearing the piece itself, I had the impression of a certain intactness of the instrumental part in relation to the libretto, the dramatical situation and acting of characters, supported by the polyphonic facture which culminates in a large fugue in the $2^{\text {nd }}$ act (this undoubtedly belongs amongst the most interesting sections of the score, and we can be grateful that it was included in the extracts). I think it was remarkable with respect to Zich's conclusions in his Estetika dramatického uměni [The Aesthetics of Dramatic Art] in which he pursues in detail the characterisational and pictorial function of music, whilst giving emphatic recommendations to opera composers about how to make music dramatically functional in relation to character and situation. One surely cannot agree with the conclusion of the enfant terrible of inter-war music journalism Antonín Šilhan, who wrote in Národni Listy after the premiere in 1922 that Zich's Guilt is 'a product of primitive dilettantism which disguises creative impotence'. However, one can agree with Jaroslav Ježek who claimed after a restored production in 1929 that the theme of the libretto is rather obsolete - one might say that today the main conflict of Hilbert's story, which takes place in the private environment of a middle-class family, is rather banal. I can't help thinking that the interpretation of a contemporary director would necessarily have led to parody and ridicule, notwithstanding the fact that there is nothing to justify this approach. Its performance (i.e. staging) will decisively influence how the
Z díla samotného jsem měla dojem určité intaktnosti instrumentální složky ve vztahu k libretu, dramatické situaci a jednání postav, posílené polyfonní fakturou, jež vrcholí rozměrnou fugou ve 2 . aktu. (Ta patří nepochybně $\mathrm{k}$ nejzajímavějším místům partitury a bud'me vděčni za to, že byla do výběru zařazena.) Přrišlo mi to jako pozoruhodné s ohledem na Zichovy závěry v Estetice dramatického umění, v níž se podrobně zabývá charakterizační a obrazivou funkcí hudby a operním skladatelům uděluje důrazná doporučení, jak učinit hudbu ve vztahu k postavě a situaci dramaticky funkční. Rozhodně se nelze ztotožnit se závěrem enfant terrible meziválečné hudební publicistiky Antonínem Šilhanem, který v Národnich listech po premiéře $\mathrm{v}$ roce 1922 napsal, že Zichova Vina je „produktem primitivního diletantismu, který zakrývá tvůrčí impotenci“. Lze se ale přiklonit k názoru Jaroslava Ježka, který na konto znovuobnovené inscenace v roce 1929 uvedl, že téma libreta je již zastaralé - řekli bychom, že dnes vyznívá hlavní konflikt Hilbertova příběhu, odehrávajícího se po vzoru Ibsenových her v privátním rodinném kruhu měštanské rodiny, jako poněkud banální. Nemůžu se ubránit dojmu, že interpretace současně cítícího režiséra by patrně vždy nevyhnutelně směřovala $\mathrm{k}$ parodii a zesměšnění, aniž by $\mathrm{v}$ dobově příznačném textu bylo cokoli, co by tento výklad ospravedlňovalo. O tom, jak budeme hudební dílo vnímat a jaký význam mu bude v dějinách hudby přikládán, rozhoduje zásadním způsobem jeho provedení. Pouze kongeniální, autorovu tvưrčímu záměru a stylu plně oddaná hudební a jevištní interpretace by mohla Zichovo dílo vynést z přítmí archivu na současnou scénu. Nejsem si však jistá, zdali chvat a začasté 
musical work will be perceived and what importance it will be assigned in the history of music. Only a congenial music and stage interpretation fully dedicated to the author's creative intention and style could bring Zich's work out of the darkness of the archive to the contemporary stage. However, I am not sure if the haste and often superficiality that we can often observe in productions of many music titles, would not be of disservice to Zich's opera.

\section{Professor Jindra Bártová}

(Music Faculty, Janáček Academy of Music and Performing Arts, Brno)

I did not like Zich's Guilt. My dissatisfaction was rooted in both the lengthy libretto and, especially, from the point of view of the uninventive musical setting. Its alleged culmination - the fugue - was stiff, without a principal theme and amateurishly developed (I'd rather say prolonged). I wish that I could say something complimentary; but I arrived at the eventual conclusion that history is often surprisingly impartial.

\section{Dr. Martin Flašar}

(Department of Musicology, Faculty of Arts, Masaryk University, Brno)

I perceive Zich's Guilt as a transitional type of opera between the Wagnerian type of romantic musical drama and modern opera. The unendliche Melodie and the technique of typical motifs are clearly taken from Wagner, whereas modern opera is represented by a civil theme, by a woman, or rather by women in the main roles, and i povrchnost, kterou lze u nás v poslední době při nastudování mnohých hudebních titulů pozorovat, by Zichově opeře neprokázaly spíše medvědí službu.

\section{prof. Jindra Bártová}

(Hudební fakulta JAMU, Brno)

Zichova Vina se mi nelíbila, a to jak z hlediska rozvleklého libreta, určeného spíše ke čtení než k jevištnímu provedení, tak - a to především - z hlediska neinvenčního zhudebnění, jehož údajný vrchol fuga - byla toporná, bez nosného tématu a školácky rozvíjená (spíš bych řekla nastavovaná). Ráda bych napsala něco pochvalného, ale tady jsem dospěla k závěru, že historie bývá kupodivu mnohdy spravedlivá...

\section{dr. Martin Flašar}

(Ústav hudební vědy FF MU, Brno)

Zichovu Vinu chápu jako přechodový typ opery mezi wagnerovským typem romantického hudebního dramatu a moderní operou. Z Wagnera se zde uplatňuje unendliche Melodie a technika příznačných motivů, k moderní opeře se Vina přiklání svým civilním námětem, ženou, resp. ženami v hlavních rolích a důrazem na polyfonní 
by an emphasis on polyphonic techniques. The fugue in the second act refers to the linear compositional thinking of the Second Viennese School, especially Alban Berg. In addition, we can consider the influence of musical expressionism as a way of examining the mental state of individuals. In any case, Zich's opera belongs to the tradition of German and Austrian opera, not the French genre. The weakest feature of the opera is the story and its adaptation. The literary libretto suffers from unnecessary literalism and the exposition of banalities.

\section{Professor Pavel Drábek}

(University of Hull, UK)

Sung Czech

Apparently the greatest positive experience of the opera was Zich's sensitive work with the Czech language. Zich's feeling for the natural cadence of the Czech language was reflected in the setting to music which intensifies (perhaps stylizes, or aesthetises) the spoken language without being violated by musical phrasing. This is a remarkable quality, which is unique in Czech opera (one might in comparison compare with Janáček).

\section{Musical texture}

Judging from the piano rendition, which flattens out the vividness of orchestration, one can claim that Zich's musical texture is recognisable and peculiar. However, it does not overshadow the main structurally dominant feature of the work, which is interpersonal conduct (à la Zich). The music intensifies, structures and emotionally develops these relationships. However, the musical component is not enlarged to the degree that it is given preference. Thus the Italian techniky. Fuga ve druhém aktu odkazuje k lineárnímu myšlení Druhé vídeňské školy, zejména Albana Berga. Kromě toho bychom mohli přemýšlet o vlivu hudebního expresionismu zkoumajícího duševní stavy jedince. V každém případě Zichova opera spadá do tradice německé (rakouské) opery, nikoliv opery francouzské. Nejslabším článkem opery je zřejmě předloha a její zpracování. Literární libreto trpí zbytečnou doslovností a exponováním banalit.

\section{prof. Pavel Drábek}

(Katedra divadelních studií FF MU, Brno)

\section{Zpívaná čeština}

Patrně největším pozitivním zážitkem opery byla Zichova citlivá práce s češtinou. Zichův cit pro přirozenou kadenci češtiny se promítl do zhudebnění, které vlastně umocňuje (stylizuje, estetizuje) mluvenou řeč, aniž by ji nějak hudební fráze znásilňovala. To je pozoruhodná kvalita, která je v české opeře jedinečná, např. ve srovnáním s Janáčkem.

\section{Hudebni textura}

Soudě z klavírního provedení, které stírá barvitost orchestrace, lze konstatovat, že Zichova hudební textura je rozpoznatelná a osobitá, zároveň ovšem nezastiňuje hlavní strukturní dominantu díla, kterou je (po zichovsku) mezilidské jednání. Hudba toto dění umocňuje, strukturuje a emočně rozvíjí, hudební složka ovšem není do té míry zbytnělá, že by se upřednostňovala. Zde tedy platí prima la azione, poi la musica. 
maxim 'prima la azione, poi la musica' [first the story, then the mucic] is valid here.

\section{Dramaturgy: Dramatic Opera}

This is apparently the dramaturgical core of Zich's Guilt: the intensification of the effect of the drama by the gesamtkunstwerk of the operatic genre. Zich's work with dramatic speech is in a way in the spirit of melodrama. The operatic adaptation of Hilbert's Guilt is a tool for intensifying the subjective experience of the story. This is the creative core of the work and, at the same time, its weak point: the opera as such in this form lacks transcendence. While we are content with the recognition that 'such is the world, and this is a picture of reality' in the work of drama, we (perhaps necessarily?) expect a certain transcendence in opera: Why should this be an opera? What is the added value? What more should we gain from the operatic version of this work than from the original dramatic work? It is possible that this added value is the specific, sensitive and aesthetic experience of the work. However, a dramaturgical question should always be: What is this opera about? How does it extend disenchanted everydayness?

\section{Dramaturgy: Psychological Realism}

Psychological Realism is probably the main pitfall of the opera and probably its biggest experiment. To transfer this specific theatrical genre into opera is a big and rather daring feat. Sung lines like 'Nazdar, Hošku' are thus unintentionally comic, because the original pathos of the genre is apparently unsustainable. This realistic literalism, which has been taken over by post-silent film and television (especially TV drama), has apparently no space in opera any more. To come to terms with psychological realism and its mimetic lit-

\section{Dramaturgie: činoherni opera}

Toto je patrně dramaturgickým jádrem Zichovy Viny: umocnění účinku činoherního dramatu gesamtkunstwerkem operního žánru. Zichova práce s činoherním slovem je svým způsobem v duchu melodramatu. Operní zpracování Hilbertovy Viny je nástrojem umocnění subjektivního prožitku tohoto př́iběhu. To je tvưrčí jádro díla a zároveň jeho slabina: opeře jako takové v této podobě chybí transcendence. Zatímco u činohry se spokojíme s poznáním, že „takový je svět a toto je obraz reality“, u opery (nutně?) čekáme jistou transcendenci: Proč to má být opera? Jaká je přidaná hodnota? Co víc získáváme z operní verze tohoto díla, než kolik nám poskytuje činohra? Je možné, že touto přidanou hodnotou je specifické citové a estetické prožití díla. Dramaturgickou otázkou pak ovšem je, o čem pak tato opera je? Čím přesahuje odkouzlenou všednodennost?

\section{Dramaturgie: psychologický realismus}

Psychologický realismus je patrně hlavní úskalí opery a patrně její největší experiment. Převést tento specifický stylový žánr do opery je velký a dosti troufalý počin. Zpívaná replika „Nazdar, Hošku“ a podobně je nechtěně komická, protože původní patos tohoto žánru je patrně neudržitelný. Tato realistická doslovnost, kterou zcela převzal zvukový film a televize (zejména televizní drama), už patrně nemá v opeře místo. Vyrovnat se s psychologickým realismem a jeho mimetickou doslovností je hlavní dramaturgická výzva inscenátorů.

\section{Dramaturgie: situace a postavy}

Naproti tomu - tedy i přes neústrojnost psychologického realismu - je Zichova 
eralism is a major dramaturgical challenge for producers.

\section{Dramaturgy: Situation and Characters}

On the other hand - despite the inorganic character of psychological realism - Zich's work with dramatic situation and characters is remarkable. It preserves the natural flow of realistic drama and it lets characters and situations keep their specificity; or, it is intensified by the means of opera. This is an important and successful element of the work.

\section{Staging Opportunities}

The main dramaturgical problem for future producers is probably to deal with the psychological realism of the work. Since Zich's opera was not continuously performed and thus it could not 'mature on stage', there is nothing to follow, which is a big problem in a traditional and conventionalized genre such as opera. Thus, the producers must span the ninety empty years in which the opera was not performed; and they must grasp it in a way which is accessible for today's audiences. This is a significant challenge, especially because works usually mature when staging approaches move from the literal to the symbolic and then from the metaphorical to de-compositional renderings. Today, it is probably impossible to stage Guilt literally, maybe symbolically and possibly metaphorically. The tenacious psychological realism of the work may be an obstacle, because it may contravene symbolic or metaphorical stagings. A great creative challenge is therefore to find a way to stage this beautiful work in its strengths: i.e. in an almost documentary austerity, combined with an emotionally impressive musical part. práce s dramatickou situací a s postavami pozoruhodná. Zachovává přirozený tok realistického dramatu a postavám i situacím ponechává jejich specifičnost, případně ji operními prostředky umocňuje. Toto je důležitý a zdařilý prvek díla.

\section{Inscenačni přiležitost}

Asi hlavním dramaturgickým problémem pro budoucí inscenátory je vyrovnat se s psychologickým realismem díla. Protože se Zichova opera nedočkala soustavného uvádění a nemohla tedy „inscenačně zestárnout", není nač navazovat, což je u tak zvykového a konvencionalizovaného žánru, jako je opera, velký problém. Inscenátoři tedy musí přemostit oněch devadesát let, kdy opera nebyla uvedena a uchopit ji tak, aby byla současnému diváku př́ístupná. To je velká výzva, zejména proto, že obvykle díla stárnou tak, že se inscenační přístup posouvá od doslovného ztvárnění, přes symbolické, dále metaforické až po dekompoziční. Doslovně dnes nelze Vinu patrně inscenovat, symbolicky snad a možná metaforicky. Zarputilý psychologický realismus díla tu může být na překážku, protože se může prŕičit symbolickému či metaforickému ztvárnění. Velkou tvưrčí př́íležitostí tedy je najít zpo̊sob, jak toto krásné dílo uvést na jeviště v jeho silných stránkách: tedy v jeho takřka dokumentaristické strohosti kombinované s emočně působivou hudební složkou. 


\section{Dr. Jiří Zahrádka}

(Department of Musicology, Faculty of Arts, Masaryk University, Brno)

I have known Guilt for a long time. I wrote about it in connection with Janáček's Fate - there are interesting parallels and a closeness of when they were written. The production was a rather pleasant surprise for me. It is formally well elaborated - even the dramaturgy is actually 'exploring'. The civil drama of the period is not really an everyday occurrence. It is one of the searching operas - in the first two decades when it was not clear what to do with the genre (in the works of Debussy, Schönberg, Bartók, Charpentier and especially Janáček). One would have to hear it in the instrumentation; but I find this opera really interesting (especially the fugue of the second act, with its distinctive psychological function) and certainly dramaturgically revealing. Hilbert slightly anticipates provincial aesthetics in the films of the First Republic; this is quite good, but something is missing - and that is the "genius of the artist'. Therefore, the opera itself is only unique in certain aspects because Zich was more of a theoretician than a composer. What am I trying to say? Well, to get a handle on what I mean, it's good to listen to another experiment - that of Janáček from 1904-5, i.e. Fate. Also the search for 'modern dramaturgy', 'modern form' and 'modern content' in opera - Janáček uses the word 'modern' in connection with Fate (but not subsequently). Janáček's text and plot are somehow interesting but a little (too) problematic - what to do with that? But the music! It brilliantly interconnects everything - and that then becomes the interpretive and emotional key to the text! Well and that's not the case with Zich. I think the opera should be performed in all its beauty - but it will be a somewhat festival-unique event.

\section{dr. Jiří Zahrádka}

(Ústav hudební vědy FF MU, Brno)

Vinu znám dlouho, psal jsem o ní v souvislosti s Janáčkovým Osudem - jsou tam zajímavé paralely i dobová příbuznost. Uvedení bylo pro mě spíše příjemné překvapení. Je to po formální stránce vypracované - i dramaturgie je vlastně „hledačská“. Soudobé civilní drama není v tehdejší opeře pravda na denním pořádku. Je to jedna z těch oper hledačských prvních dvou desetiletí, kdy nebylo jasné, co s tímto žánrem (Debussy, Schönberg, Bartók, Charpentier a hlavně Janáček). Člověk by to musel vyslechnout v instrumentaci, ale jeví se mi ta opera skutečně zajímavá (třebas ta fuga v 2. jednání - výrazná psychologická funkce), dramaturgicky jistě objevná. Malinko Hilbert předráží jistou maloměštáckou estetiku filmu první republiky. No prostě je to dobrý, ale něco tomu chybí. A to je ten „genius tvůrce“. Proto ta opera není výjimečná jako taková, jen pro určité aspekty. Zich byl skutečně spíše teoretik nežli skladatel. Co tím chci říci? Nu je dobré si poslechnout jiný experiment - ten Janáčkův z let 1904-5, tedy Osud. Také hledání „moderní dramaturgie“, „moderní formy“ a "moderního obsahu“ opery - Janáček slovo moderní v souvislosti s Osudem užívá (potom už ne!). Nu text i děj je jaksi zajímavý, ale trochu (moc) problematický - co s ním? Ale ta hudba!!! Ta vše tak geniálně propojí - je klíčem k tomu textu! Nu, a to u Zicha není. Myslím, že by se opera měla nastudovat v celé kráse - ale bude to spíše počin festivalovo-výjimečný. 


\section{Patricie Částková}

(Dramaturg of the Opera of the National

Theatre Brno)

The world of opera in theatres - if their dramaturgy is not clearly defined as for example in Theater an der Wien - has unfortunately been limited to a few dozen works in the last few decades. It is a pity with regards to the richness offered by the more than four-hundred-year-old history of opera. And even though the opera Guilt (1911-1915) by the Czech aesthetician and composer Otakar Zich will never be considered a discovered treasure, the half-scenic production of several parts at the Structural Approaches to Art conference provided a very interesting view into opera-making and creative research at the beginning of the $20^{\text {th }}$ century. The entire first act, Mrs. Mařáková's song, the fugue from the $2^{\text {nd }}$ act, and the closing part of the opera were presented at the scenic concert. Zich's Guilt was written at the same time that Janáček composed Jenufa, Fate and he was working on the Excursions of Mr. Brouček. This, in itself, provides an interesting comparison, e.g. in the text selection of the play to be set to music. Guilt, as well as Jenufa, was based on a theatre play, in this case on J. Hilbert's play of the same name; but it is obvious in selected parts that the composer lacks the ability to interfere with the text so as to make the dramatic shortcuts that are so needed in opera, although in the vocal parts he often works with the text in a parlando style. The extracts were accompanied by two pianos, since even a tiny glimpse into the score shows that the orchestra needed for the production of the work would hardly fit in the orchestral pit of the Janáček Theatre. Therefore, it is difficult to say what the real impression of

\section{Patricie Částková}

(dramaturgyně Opery Národního divadla Brno)

Svět operních děl v divadlech, pokud není jejich dramaturgie skutečně vyhraněna jako například ve vídeňském Theatre an der Wien, se v posledních desetiletích bohužel často omezuje na několik málo desítek titulů. Vzhledem k bohatství, které nám skýtá více než čtyřsetletá historie opery, je to škoda, a i když opera Vina (1911-15) českého estetika a skladatele Otakara Zicha asi nikdy nebude považována za objevený poklad, poloscénické uvedení jejích částí v rámci konference Structural Approaches to Art poskytlo velmi zajímavý pohled do operního varu a hledání na počátku 20. století. Na scénickém koncertu zaznělo celé 1. jednání, píseň paní Mařákové a fuga z 2. jednání a závěr opery. Zichova Vina vznikala v době, kdy měl Janáček za sebou kompozici Jeji pastorkyně, Osudu a pracoval na Výletech páně Broučkouých. To samo o sobě poskytuje zajímavé srovnání např. ve smyslu volby textu divadelní hry jako východiska ke zhudebnění. Stejně jako Jeji pastorkyňa je Vina založena na divadelní hře, zde na stejnojmenné hře J. Hilberta, ale i ve vybraných částech je znát, že skladateli chyběla schopnost zasáhnout do textu a dosíci v opeře tolik potřebné dramatické zkratky, ač s textem ve zpěvních partech pracuje často parlandovým zpo̊sobem. Úryvky zazněly v úpravě pro dva klavíry, nebot' i letmý pohled do partitury ukáže, že orchestr potřebný $\mathrm{k}$ provedení díla by se stěží směstnal do orchestřiště Janáčkova divadla. Proto těžko soudit jaké by bylo skutečné vyznění opery, protože orchestrální part slibuje být tou zajímavější částí. 
the opera would be since the score of the orchestra seems to be the most interesting part. We will not probably live to see a complete production of Guilt in the theatre; but even this short look is a praiseworthy deed and university conferences could be the ideal place for presenting forgotten works, which provide an interesting testimony to their periods of origin.

\section{Hana Kovaříková}

(Theatre Director)

Zich's Guilt surprised me in some ways and considerably exceeded my expectations. Based on Otakar Zich's theoretical works and a rough knowledge of the plot of the opera, I had formed a misleading idea about what I was going to hear.

Hilbert's romantic, moving story about secret passion, hurt feelings and intensive reproaches that push the character of Mína to commit suicide, was composed by Zich with unconcerned matter-of-factness and pragmatic prudence. From one listening (and only at the dress rehearsal at which the conductor, performers and orchestra just followed the score rather than focusing on a more deeply-felt, expressive interpretation) it is difficult to illustrate this with specific examples, but the melodic lines seemed to be deliberately stylised according to the intonation of spoken language, concentrating more on the themes content (and punctuation) of dialogues, and not on motifs and musical thoughts. Instead of the expected melodramatic (i.e. moving and touching) spirit of the work, I could not help thinking about the formal affinity of Modernist opera and Melodrama when listening to this richly-structured and
Asi se dnes těžko dočkáme kompletního uvedení Viny v divadle, ale alespoň krátké nahlédnutí je velmi záslužným činem, a právě univerzitní konference by mohly být ideálním místem pro provádění dnes již zapomenutých děl, která jsou zajímavým svědectvím o době svého vzniku.

\section{Hana Kovaříková}

(divadelní režisérka)

Zichova Vina mě v několika ohledech překvapila a výrazně předčila má očekávání. Na základě teoretických děl Otakara Zicha a zároveň při zběžném povědomí o ději opery, utvořila jsem si předem zcela zavádějící představu o tom, co uslyším.

Romantický, dojímavý Hilbertův příběh o utajené vášni, o zraněných citech a intenzivních výčitkách, které doženou postavu Míny až k sebevraždě, komponuje Zich s jakousi nezúčastněnou věcností a pragmatickou rozvahou. Z jednoho poslechu (navíc z provedení na generální zkoušce, kde ještě dirigent, interpreti a orchestr sledovali spíše literu partitury než procítěnou výrazovou interpretaci) je těžké to doložit konkrétními př́íklady, ale melodické linky se mi zdály jako záměrně stylizované podle intonací mluvené řeči, ř́dily se obsahovými tématy (a interpunkcí) dialogu, nikoli motivy a myšlenkami hudebními. Místo očekávaného melodramatického (rozuměj pohnutého a jímavého) ducha díla, jsem se při poslechu toho bohatě strukturovaného a složitě komponovaného hudebního materiálu neubránila úvahám o formální spřízněnosti modernistické opery a melodramu. Na 
intricately-composed musical material. My overall impression of musical 'distance' was surely influenced by Locke's arrangement for two pianos, which certainly reduced the colouring and the dynamic range of the original arrangement. The impersonalised concept was also reflected in the form of a concert production interspersed with distant and lightweight spoken comments.

Whilst Zich's theoretical papers about theatre and music aesthetics have always seemed to me clearly straightforward, logically simplifying and generalizing, Zich's music had the opposite impact on me: mathematicallyconstructed, continuously-changing in specific, unrepeated details, without any overall musical theme or leitmotif. The composer Zich assumed the musical erudition of the audience, his composition is demanding because it is not superficially appealing, harmonising or rhythmically thrilling. Thus, the relatively conservative and occasionally popular-scientific aesthetician revealed to me the Modernist, experimental and sophisticatedly playful personality of the same man as a composer.

It is also difficult to estimate the final effect of the director's approach from the dress rehearsal; but from what I saw, I must say that the chosen tools seemed to me adequately sensitive, and, despite a certain minimalism, sufficiently revealing and just effective enough (a sketchy mise-en-scène, gentle changes in projection etc.) not to distract attention from this demanding dramatic music piece. Thus, I appreciated both the dramaturgical revelation and the professional and inspirational rendition of the piece. celkovém dojmu hudebního „odstupu“ měla jistě podíl i Lockeho úprava pro dva klavíry, která samozřejmě ubrala na barevnosti a dynamickém rozsahu původního aranžmá. Odosobněnému pojetí odpovídala i forma koncertního provedení prokládaného zcizujícími a odlehčenými mluvenými vstupy.

Zatímco teoretické Zichovy spisy o divadelní a hudební estetice mi vždy připadaly přehledně přímočaré, zdravě zjednodušující a zobecňující, Zichova hudba na mě působila zcela opačně: matematicky vykonstruovaná, neustále se proměňující v konkrétních neopakujících se detailech, bez jednoho zastřešujícího hudebního tématu či leitmotivu. Zich skladatel předpokládá divákovu hudební erudici, jeho kompozice je náročná, protože není prvoplánově melodicky líbivá, harmonizující či rytmicky strhující. Relativně konzervativní a místy až populárně naučný estetik mi tak odhalil svou modernistickou, experimentující a sofistikovaně hravou povahu komponisty.

Z generální zkoušky je rovněž těžké odhadnout výsledný účinek režijního pojetí, ale z toho, co jsem viděla, musím říct, že mi zvolené prostředky připadaly adekvátně citlivé, přes jistý minimalismus dostatečně sdělné a tak akorát efektní (náznaková mizanscéna, nenásilné proměny projekce atd.), aby neodpoutávaly pozornost od již tak dost náročného hudebně-dramatického kusu. Oceňuji tedy jak dramaturgickou objevnost, tak profesionální a inspirativní provedení tohoto kusu.

(psáno na základě generální zkoušky 8. 6. 2018) 


\section{Hana Hložková}

(Radio Dramaturg)

The encounter with Zich's Guilt was a very pleasant surprise for me as a listener. Even though the plot is easy to follow (since the opera has almost no storyline), and the work itself is too extensive (the scenic concert had the advantage of being shortened), the music and vocal parts seemed to me so suggestive that I would like to hear the entire opera. However, I think that the work is intended for a patient audience one that is used to demanding pieces, and for very inventive producers who could change the drawbacks of the opera (too many psychological parts, little action, obsolete themes) into a more vital stage production. Guilt is generally not known, which is a pity, because it is undoubtedly an interesting Modernist work which deserves to be performed more often.

\section{Bibliography}

LEŠKA, Rudolf. 2018. Zichova ibsenovská opera. Divadelni noviny 27 (2018): 13: 7.

HOFFMANOVÁ, Karla. 2018. Otakar Zich a jeho zapomenutá opera Vina. Hudebni rozhledy 71 (2018): 8: 30-31.

PAVLICA, Lukáš. 2018. Zichova Vina jako scénický koncert. Časopis Harmonie [online]. (11. 6. 2018). Available online at: https:// www.casopisharmonie.cz/kritiky/zichovavina-jako-scenicky-koncert.html

\section{Hana Hložková}

(rozhlasová dramaturgyně)

Pro mě osobně bylo setkání se Zichovou Vinou velmi př́jemným posluchačským překvapením. I když je zápletka takřka bezdějové opery snadno odhalitelná a dílo samotné je př́liš rozsáhlé (scénický koncert měl tu výhodu, že byl krácen), hudba a pěvecké party mi připadly sugestivní natolik, že bych si operu ráda vyslechla celou. Domnívám se ale, že je to dílo určené pro trpělivé posluchače, zvyklé na náročnější kusy, a velmi invenční inscenátory, kteří by nevýhody této opery (příliš mnoho psychologických partů, málo akce, zastaralé téma) dokázali proměnit v životnější jevištní tvar. O Vině se v obecném povědomí spíš neví, což je škoda, protože je bezesporu zajímavým modernistickým dílem, které by si zasloužilo být více prezentováno.

\section{Bibliografie}

LEŠKA, Rudolf. 2018. Zichova ibsenovská opera. Divadelni noviny 27 (2018): 13: 7.

HOFFMANOVÁ, Karla. 2018. Otakar Zich a jeho zapomenutá opera Vina. Hudebni rozhledy 71 (2018): 8: 30-31.

PAVLICA, Lukáš. 2018. Zichova Vina jako scénický koncert. Časopis Harmonie [online]. (11. 6. 2018). Dostupné online: https://www. casopisharmonie.cz/kritiky/zichova-vinajako-scenicky-koncert.html 
